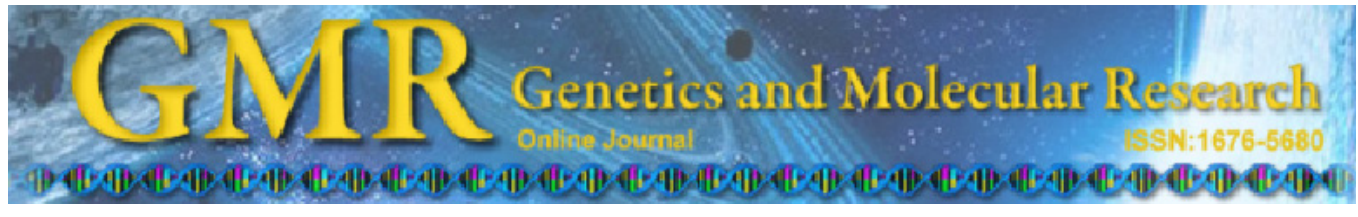

\title{
Environmental and genetic factors affecting the weaning-estrus interval in sows
}

\author{
C.D.S. Leite ${ }^{1}$, J.F. Lui ${ }^{2}$, L.G. Albuquerque ${ }^{2}$ and D.N.M. Alves $^{3}$ \\ ${ }^{1}$ Departamento de Zootecnia, Universidade Federal de Viçosa, \\ Viçosa, MG, Brasil \\ ${ }^{2}$ Departamento de Zootecnia, \\ Universidade Estadual Paulista "Julio de Mesquita Filho", \\ Jaboticabal, SP, Brasil \\ ${ }^{3}$ Universidade Federal Rural do Amazonas, Campus de Parauapebas, \\ Parauapebas, PA, Brasil \\ Corresponding author: C.D.S. Leite \\ E-mail: carla.leite@ufv.br
}

Genet. Mol. Res. 10 (4): 2692-2701 (2011)

Received January 18, 2011

Accepted July 5, 2011

Published November 4, 2011

DOI http://dx.doi.org/10.4238/2011.November.4.2

\begin{abstract}
We examined the effects of environmental and genetic factors on the weaning-to-estrus interval (WEI) in sows. In order to perform the analyses of the environmental factors, 8104 observations of the 1 st to the 6 th WEI were carried out, while 6548 observations of the 1 st to the $3 \mathrm{rd}$ WEI were carried out for the analyses of genetic factors. The environmental model included as fixed effects, herd, genetic line, year and season of birth, as well as the covariates, age of sow at farrowing, litter size at birth and lactation length. Genetic analysis was performed by repeatability and multitrait models. The mean and coefficient of variation for WEI were 7.02 days and $100.6 \%$, respectively. The linear effect of lactation length and the quadratic effect of the age of sow at farrowing affected the WEI. Herd, year and season of farrowing were significant sources of variation for WEI, and there was no influence of genetic line or of litter size at birth. Heritability estimated by the repeatability model was 0.04 , while heritabilities obtained by the multitrait model were
\end{abstract}


$0.07,0.02$ and 0.07 for the first three WEI, respectively. Estimates of genetic correlations among the different WEI were of moderate to low magnitude. It was concluded that environmental factors, such as year and season of farrowing, lactation length, age of sow at farrowing and herd, should be considered in the model for best estimation of genetic parameters for this trait. Although with only a small possible genetic gain, selection can be made based on the first WEI.

Key words: Repeatability; Multitrait model; Non-genetic factors; Heritability

\section{INTRODUCTION}

In order to evaluate the reproductive efficiency of the sow, one of the parameters analyzed is the farrowing number per sow per year, which is directly influenced by lactation to farrowing length as well as weaning-estrus interval (WEI). It comprises the day of weaning to the new manifestation of estrus, which is usually detected by the immobility reflex of the sow.

The WEI may be considered as a non-productive day of the sow and this is an economically relevant trait for commercial swine production because longer sow non-productive days increase maintenance costs and decrease sow efficiency (Chansomboon et al., 2009).

Environmental and genetic factors may influence reproductive and productive traits of swine (Cavalcante-Neto et al., 2008a, 2009a,b). The WEI is usually associated with parity number, estrus length, the time of ovulation, and previous litter size (Karveliene et al., 2008; Cavalcante-Neto et al., 2008b), and it may be also influenced by other environmental factors such as season, temperature, photoperiod, nutrition, stress, age of the sow, management practices, genetic, among others (Antunes, 2007; Lundgren et al., 2010).

WEI could be considered a longitudinal trait in that it occurs more than once in the lifetime of the animal, and the repeatability model is commonly used to estimate its components of variance (Tholen et al., 1996; Adamec and Johnson, 1997; Chansomboon et al., 2010). This model assumes that correlations among the different intervals are equal to the unity, i.e., the same genes control the trait in all intervals. This is a very simplistic approach, since there is the multitrait, in which each interval is considered to be a distinct trait, and the correlations are considered to be different from the unity (Roehe and Kennedy, 1995; Noguera et al., 2002; Holm et al., 2005).

Thus, the aim of this study was to analyze the environmental factors on the WEI and to estimate genetic parameters by repeatability and multitrait models.

\section{MATERIAL AND METHODS}

Data from two commercial maternal lines were used. The initial file consisted of 13,934 farrowings, which occurred during the period from December 2004 to August 2007, in two nucleus farms that housed both animal genetic lines. The farms were located in the United States. In order to verify the effect of the farrowing season on the WEI, the months in which the parities have occurred were grouped into four trimesters: 1 - from December to February; 2 - from March to May; 3 - from June to August, and 4 - from September to November. 
In order to assess the data analysis, some restrictions were made. WEI observations that were greater than 42 days, age at first farrowing less than 200 days and lactation lengths longer than 32 days were eliminated since they are considered to be outside the normal sow physiologic parameters. Sows that presented, in the data file, only information of the first farrowing were also excluded from the analysis. These restrictions led to a drop of $41.8 \%$ of the observations, with 8104 WEI data remaining from the first to the sixth parities. In order to obtain a better normality of the error distribution in the WEI trait, this was transformed by the logarithmic formula developed by Ten Napel et al. (1995), which has been used by several authors (Hanenberg et al., 2001; Holm et al., 2005; Imboonta et al., 2007).

The analysis of environmental factors was performed using the SAS software (1999), using MIXED procedure (PROC MIXED) and adjusting the data by the maximum likelihood method with REPEATED option for repeated measures in the time. The model used to describe WEI variations can be represented as follows:

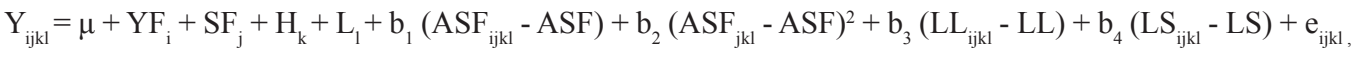

where $Y_{i j k l}$ is the observed value of the WEI trait; $\mu$ is the overall mean associated with each observation; $Y F_{i}$ is the fixed effect of the 1st year of farrowing (2005, 2006 and 2007); $S F_{j}$ is the fixed effect of the 1st season of farrowing $(1,2,3$, and 4$) ; H_{k}$ is the fixed effect of $\mathrm{k}^{\text {th }}$ herd of birth ( 1 and 2); $L_{l}$ is the fixed effect of $1^{\text {th }}$ lineage ( 1 and 2$) ; b_{1}$ and $b_{2}$ are the coefficients of linear and quadratic regression of the trait in relation to age of sow at farrowing, respectively; $A S F_{i j k l}$ is the age of sow at farrowing; $A S F$ is the average age of sow at farrowing, $b_{3}$ is the coefficient of linear regression of the trait in relation to lactation length; $L L_{i j k l}$ is the lactation length; $L L$ is the average of lactation length, $b_{4}$ is the coefficient of linear regression of the trait in relation to the total size of the litter at birth; $L S_{i j k l}$ is the litter size at birth in the previous cycle, $L S$ is the average litter size at birth in the previous cycle, and $e_{i j k l}$ is the random error associated with each observation, with $\mu=0$ and variance $=\sigma_{\mathrm{e}}^{2}$.

The effects of all possible interactions among the fixed effects were tested, but the ones that did not present a statistical significance $(\mathrm{P}>0.05)$ were excluded from the analysis. Similarly, the covariates were tested in the linear and quadratic form, but only the linear form was retained when they did not present significance $(\mathrm{P}>0.05)$.

For genetic analysis, contemporary groups (CG) were formed by the year of farrowing (2005 to 2007), the season of farrowing (1, 2, 3, and 4), the herd (1 and 2), and lines (1 and 2). Some restrictions were adopted in the genetic analyses. Only CGs with at least four observations were kept in the dataset, and only information about sows that were the offspring of boars with at least three female offspring and of dams with at least two female offspring was considered. It was also defined that observations of WEI over the third parity order were also excluded from the genetic analysis due to the small number observed. After the restrictions were made, 6548 WEI of 2903 sows, which were the offspring of 188 boars and 1300 dams, remained in the dataset.

Before the (co)variance analysis, the SECATEURS program (Meyer, 2003) was used to eliminate animals that were not informative to the relationship matrix from the pedigree file. Therefore, after these discharges, the relationship matrix was composed of 4605 animals.

For the repeatability model, there were included as fixed effects, the contemporary group and the covariates age of sow at farrowing and lactation length, both in the linear form. 
The additive genetic and permanent environmental effects were used as random effects. The model can be represented in matrix form as follows:

$$
y=X \beta+Z 1 a+Z 2 \delta+\varepsilon
$$

where $y$ is the vector of observations; $X$ is the incidence matrix of the fixed effects (contemporary group, age of sow at farrowing and lactation length), $\beta$ is the vector of fixed effects; $Z_{I}$ is the incidence matrix of the direct additive genetic effects (sows and boars), $\alpha$ is the vector of direct additive genetic effects; $Z_{2}$ is the incidence matrix of the permanent environmental effects (sows with repeated measures), $\delta$ is the vector of permanent environmental effects, and $\varepsilon$ is the vector of the residual effect. The assumed assumptions were that $\mathrm{E}(\mathrm{y})=\mathrm{X} \beta$,

$$
\mathrm{E}(\alpha)=0, \mathrm{E}(\delta)=0 \text { and } \mathrm{E}(\varepsilon)=0 .
$$

When each weaning-to-estrus interval as different trait was considered, the multitrait model was applied. Permanent environmental effect and age of the sow at farrowing were excluded from this model.

Estimates of the variance components were obtained by the derivative-free restricted maximum likelihood method, which is applied in animal models. For the repeatability model analysis, the MTDFREML program was used (Boldman et al., 1995), whereas for multitrait model the REMLF90 program (Misztal, 2002) was used. A simplex variance of values (-2 $\log _{\mathrm{e}}$ of likelihood) lower than $10^{-9}$ was used as convergence criterion. After each convergence, the program was restarted, with the estimates of the previous apparent convergence used as initial values, until an apparent global minimum was found and the estimates of genetic parameters did not change between runs. It was assumed that the co-variances among the effects were equal to zero.

\section{RESULTS AND DISCUSSION}

The mean and the coefficient of variation obtained for the WEI were 7.02 and $100.6 \%$, respectively. These values were similar to those reported in the literature (Tholen et al., 1996; Karveliene et al., 2008). However, Ten Napel and Johnson (1997) have found higher means, while lower means were reported by Carregaro et al. (2006) and Poleze et al. (2006).

High coefficient of variation found corroborates with those obtained in the literature (Tholen et al., 1996; Ten Napel and Johnson, 1997; Carregaro et al., 2006; Poleze et al., 2006), confirming high WEI variation within the population. According to Cavalcante-Neto et al. (2008b), this may be the result of a lack of qualified professionals in farms, which makes the detection of the estrus in animals difficult, since the female could present reflection of tolerance to the boar, and does not present it to the man.

A quadratic relationship $(\mathrm{P}<0.0001)$ between WEI and the age of the sow at farrowing was observed (Table 1). This result corroborates the findings of Cavalcante-Neto et al. (2008b).

This is due to the primiparous sows being more susceptible to prolonged WEI (Figure 1), requiring higher demand of nutrients for their growth, since they have not yet reached adult size and weight, having limited body reserves of protein and fat, requiring higher demand of nutrients for their growth. These higher nutritional demands for growth in addition 
to nutritional demands to milk production for their first litter may have strained their ability to return to estrus as quickly as multiparous sows after weaning (Chansomboon et al., 2009). Thus, besides the demands for milk production and maintenance, they also demand energy for their growth (Poleze et al., 2006). These sows do not have a satisfactory feed intake during lactation, which is a critical period and is decisive for subsequent reproductive performance, causing weight loss during lactation (Karveliene et al., 2008), hence delaying the heat and, thus, increasing the WEI.

\section{Table 1. Analysis of variance for the weaning-estrus interval of sows.}

\begin{tabular}{lcc}
\hline Source of variation & MS & $\mathrm{F}>\mathrm{P}^{*}$ \\
\hline Year of farrowing & 13.73 & $<0.0001$ \\
Season of farrowing & 7.68 & $<0.0001$ \\
Genetic line & 0.69 & 0.4073 \\
Herd & 9.53 & 0.002 \\
Age of sow at farrowing (linear) & 21.55 & $<0.0001$ \\
Age of sow at farrowing (quadratic) & 14.57 & $<0.0001$ \\
Lactation length (linear) & 4.24 & 0.0395 \\
Litter size (linear) & 1.66 & 0.1953 \\
\hline
\end{tabular}

MS $=$ mean square. ${ }^{*}$ Value of probability.

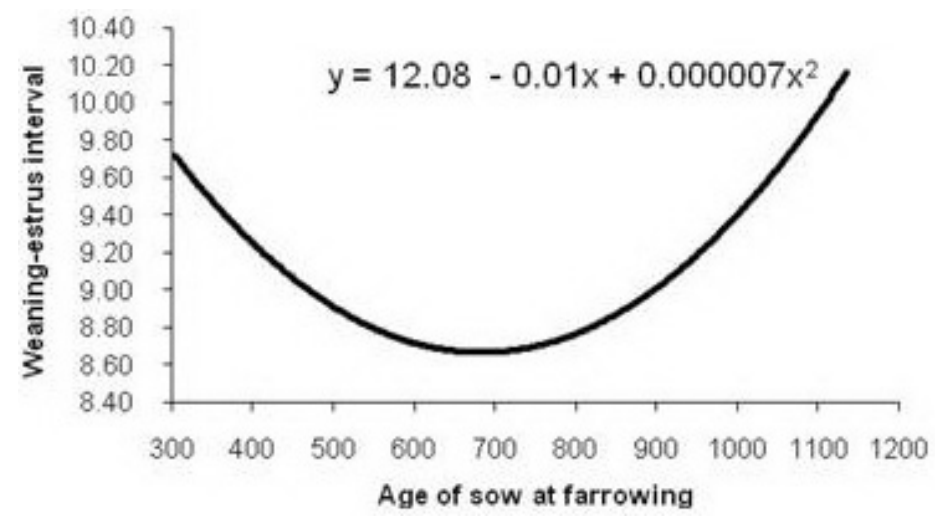

Figure 1. Estimation of weaning-estrus interval (in days), by age of sow at farrowing (in days).

In sows over the age of 900 days, WEI increase was also observed in relation to the sow age between 500 and 900 days (Figure 1), which is due to sows that have gone past a phase of greater reproductive performance, which leads to larger litters and hence greater physiological exhaustion. According to Cavalcante-Neto et al. (2008b), this could decrease the reproductive performance in the subsequent farrowing.

Lactation length was positively and linearly related $(\mathrm{P}<0.001)$ with WEI (Table 1), and this has previously been documented in the literature (Carregaro et al., 2006; Cavalcante-Neto et al., 2008b; Karveliene et al., 2008). Lactation length increase causes an increase in the WEI. This fact could be due to greater weight loss after the third week of lactation. According to Guedes and Nogueira (2001), there is a significant positive correlation between the increase in the lactation length and weight loss. Controversial results, however, can be found in the literature. A quadratic relationship between 
lactation length and WEI was reported by Mabry et al. (1996), Poleze et al. (2006), and Chansomboon et al. (2009). The WEI reduction caused by the increase in the lactation length was described by Koketsu and Dial (1997) and Tummaruk et al. (2000). However, no influence by lactation length was reported by Tantasuparuk et al. (2000) and Chansomboon et al. (2010).

These differences found in the literature may be attributed not only to genetics but also to other factors directly related to lactation, such as feed intake during this period, the sow body waste during the lactation period (which occasionally causes a reduction on the exposure to the boar and litter size (Mabry et al., 1996; Antunes, 2007; Cavalcante-Neto et al., 2008b). Thus, the relationship between WEI and lactation length should always be verified in the herd, which is under study, because, as it has already been observed, it varies from population to population and may be subject to control in the management system, whereas the farrowing parity, season and litter size are factors more difficult to control (Koketsu and Dial, 1997).

According to the observations, there was no effect of genetic line on the WEI, which confirms the report of Poleze et al. (2006), who have reported that the genotype does not directly interfere in the WEI, but indirectly interferes through genetic variation in the susceptibility of the factors that may prolong this interval. The year and season of farrowing caused significant differences, contradicting the findings of Cavalcante-Neto et al. (2008b). It was observed that the lowest WEI was obtained in the fourth season of farrowing (Table 2), September-November, which corresponds to the fall season, while during summer, from June to August, sows had longer WEIs. These results are consistent with those obtained by Karveliene et al. (2008) for the weaning month of sows in Lithuania.

The difference obtained in the WEI among the seasons of farrowing may be related to the voluntary feed intake, especially during lactation, which is influenced by environmental temperature. According to Bortolozzo and Wents (2004), it is common to observe satisfactory consumption in winter and lower consumption in summer.

Table 2. Variation on the weaning-estrus interval (WEI) means by the season of farrowing.
\begin{tabular}{lccc}
\hline WEI & Number of observation & Mean (days) & Standard deviation (days) \\
\hline Season of farrowing & & & 6.49 \\
1 - December-February & 2816 & 6.74 & 7.14 \\
2 - March-May & 1131 & 7.46 & 8.17 \\
3 - June-August & 1906 & 7.67 & 6.76 \\
4 - September-November & 2161 & 6.68 & \\
\hline
\end{tabular}

The heritability obtained by the repeatability model was low (Table 3 ), indicating that the phenotype would not be good indicator for the genotype of individuals. This result is in agreement with those reported by Tholen et al. (1996), which have found heritabilities of 0.10 and 0.08 for two swine herds in Australia. Hanenberg et al. (2001) found heritability of 0.07 using repeatability model that considered from the second to sixth interval and 0.14 when it was considered only the first interval.

Higher heritabilities were, however, reported ranging from 0.11 to 0.44 (Ten Napel et al., 1995; Adamec and Johnson, 1997; Hanenberg et al., 2001; Imboonta et al., 2007; Cavalcante-Neto et al., 2008b).

The repeatability estimated was 0.08 , which is very close to the value found by Chansomboon et al. (2010). These low repeatability estimates emphasize the importance of obtain- 
ing several records per sow for weaning to insemination interval and litter traits to improve the prediction accuracy of future records of sows as well as to increase the prediction accuracy of sow, boar and progeny in swine populations (Chansomboon et al., 2010).

$\begin{aligned} & \text { Table 3. Estimates of additive genetic variance }\left(\sigma_{\mathrm{a}}^{2}\right) \text {, permanent environmental }\left(\sigma_{\mathrm{p}}^{2}\right) \text { and error }\left(\sigma_{\mathrm{e}}^{2}\right) \text {, heritability } \\
& \text { estimates }\left(\mathrm{h}^{2}\right) \text {, and repeatability for the interval from weaning to estrus (WEI). }\end{aligned}$
\begin{tabular}{lccccc} 
WEI & $\sigma_{\mathrm{a}}^{2}$ & $\sigma_{\mathrm{p}}^{2}$ & $\sigma_{\mathrm{e}}^{2}$ & $\mathrm{~h}^{2}$ & $\mathrm{r}$ \\
\hline Repeatability & 0.42 & 0.42 & 9.28 & 0.04 & 0.08 \\
Multitrait & & & & & \\
WEI 1 & 0.84 & - & 11.16 & 0.07 & 0.02 \\
WEI 2 & 0.20 & - & 8.45 & 0.07 & \\
WEI 3 & 0.60 & - & & 8.18 & \\
\hline
\end{tabular}

Low estimates of additive genetic variance $\left(\sigma^{2}\right)$ and, consequently, low heritabilities presented indicate that there is little influence of genes on the traits. According to Chansomboon et al. (2009), the low estimate of additive genetic variance found in their study may indicate that the number of boars and sows used to generate the population was small, and that perhaps many of these original animals were related.

In this case the variation found may be explained by the environmental influences, or it could be due to the lack of accuracy in the detection of estrus (Kim, 2001), once the failure to detect the exact first estrus after weaning makes it difficult to identify animals that present estrus earlier, assigning a prolonged interval, which does not represent their actual range. According to Cavalcante-Neto et al. (2008b), the lack of skilled workers is the main factor of the WEI high variation among the sows. According to Silveira et al. (1998), it may occur because, despite being in heat, females do not immobilize to the back pressure test to trigger the tolerance reflex, making the detection difficult.

Low values of heritability were also described by Hanenberg et al. (2001) and Kim (2001), both using the multitrait model. However, contrary to these study results, the estimates found by both authors declined over the intervals. Imboonta et al. (2007) have reported greater heritability estimates than in the present study, using multitrait analysis. Its values were 0.16 , 0.16 and 0.18 for the first, second and third WEI, respectively.

Genetic correlation estimates among the intervals were all positive and of moderate to low magnitude, except between the first and third WEI, in which the estimate was higher than 0.7 (Table 4). The values found in literature are mostly higher than those obtained in this study, as the ones verified by Hanenberg et al. (2001), who considered the interval between weaning and the first insemination, and found genetic correlation estimates ranging between 0.79 and 0.97 for six intervals, while Kim (2001) reported genetic correlation estimates of $0.65,0.71$ and 0.83 for the first three intervals, respectively.

Table 4. Phenotypic correlations (below of the diagonal) and genetic correlations (above of the diagonal) among the different intervals in multitrait analysis for the trait weaning-estrus interval (WEI).

\begin{tabular}{lccc}
\hline WEI & 1 & 2 & 3 \\
\hline 1 & 0.07 & 0.49 & 0.74 \\
2 & 0.10 & 0.02 & 0.72 \\
3 & 0.06 & 0.07 & 0.07 \\
\hline
\end{tabular}


Genetic correlations that are different from the unit indicate that estimating genetic parameter using repeatability model is not the most suitable method. In the population studied, it was more appropriate to use genetic parameters obtained by the multitrait model. Likewise, when estimating genetic parameters for reproductive traits among primiparous and multiparous WEI, Oh et al. (2006) have reported that the genetic correlation estimates were not high enough to consider WEI observations of primiparous and multiparous to be a single trait.

The high genetic correlation obtained in this study between the first and third WEI indicates that most genes, which act during the first interval, also operate during the third, i.e., the best animals in the first interval may also be in the third WEI. This fact suggests that selection based on the first WEI could be done, which would possibly cause a WEI decrease in the subsequent farrows. However, it is known that the correlated answer depends not only on genetic correlation among traits but also on heritability of traits involved in the selection process. Thus, despite the high genetic correlations among these intervals, correlated response by indirect selection, although effective, would result in low genetic gains, due to the low heritability obtained.

Thus, considering each weaning-estrus interval as a distinct trait may be convenient to estimate genetic parameters. The previous reproductive cycle may affect subsequent farrowing due to the effect of selection and permanent environment (Oh et al., 2006).

The phenotypic correlations obtained were all low (Table 4), indicating that the weaning-estrus intervals have little phenotypic dependence. Higher estimates, ranging from 0.08 to 0.19 , were obtained by Hanenberg et al. (2001). Thus, it is hoped that better progress on the reproductive performance of the sows will result from manipulation of environmental factors, rather than genetic changes.

\section{CONCLUSION}

We concluded that environmental factors, such as lactation length, age of the sow at first farrowing, herd, year and season of farrowing, should be considered in the model for better estimation of genetic parameters for the weaning-estrus interval. The selection may be performed based on the first weaning-estrus interval, although the genetic gain is small.

\section{ACKNOWLEDGMENTS}

The authors are grateful to CAPES for the financial support and thank Dr. Fabiano Veraldo da Costa Pita for providing the data and Aderbal Cavalcante-Neto for his help in this study.

\section{REFERENCES}

Adamec V and Johnson RK (1997). Genetic analysis of rebreeding intervals, litter traits and production traits in sows of the National Czech nucleus. Liv. Prod. Sci. 48: 13-22.

Antunes RC (2007). Manejo reprodutivo de fêmeas pós-desmame com foco sobre o intervalo desmame cio (IDC). Rev. Bras. Rep. Anim. 31: 38-40.

Boldman KG, Kriese LA, Van Vleck LD and Van Tassel CP (1995). A Manual for Use of MTDFREML. A Set of Programs to Obtain Estimates of Variances and Covariances (DRAFT). U. S. Department Agriculture, Agriculture Research Service, Clay Center, Nebraska.

Bortolozzo F and Wentz I (2004). Intervalo Desmame-Estro e Anestro Pós-Lactacional em Suínos. Editora Pallotti, Porto Alegre. 
Carregaro FB, Mellagi APG, Bernardi ML, Wentz I, et al. (2006). Reflexo do período de lactação na produtividade de porcas primíparas e multíparas. Acta Sci. Vet. 34: 39-43.

Cavalcante-Neto A, Lui JF, Sarmento JLR, Ribeiro MN, et al. (2008a). Efeitos genéticos e ambientais sobre a idade à primeira concepção de fêmeas suínas. Arq. Bras. Med. Vet. Zootec. 60: 499-502.

Cavalcante-Neto A, Lui JF, Sarmento JLR, Ribeiro MN, et al. (2008b). Fatores ambientais e estimativa de herdabilidade para o intervalo desmame-cio de fêmeas suínas. Rev. Bras. Zootec. 37: 1953-1958.

Cavalcante-Neto A, Lui JF, Sarmento JLR and Ribeiro MN (2009a). Efeitos genéticos e não-genéticos sobre o intervalo de parto em fêmeas suínas no Sudeste do Brasil. Arq. Bras. Med. Vet. Zootec. 61: 280-285.

Cavalcante-Neto A, Lui JF, Sarmento JLR and Ribeiro MN (2009b). Estimation models of variance components for farrowing interval in swine. Braz. Arch. Biol. Technol. 52: 69-76.

Chansomboon C, Elzo MA, Suwanasopee T and Koonawootrittriron S (2009). Genetic and environmental factors affecting weaning-to-first service interval in a landrace-large white swine population in northern Thailand. Kasetsart J. (Nat. Sci.) 43: 669-679.

Chansomboon C, Elzo MA, Suwanasopee T and Koonawootrittriron S (2010). Estimation of genetic parameters and trends for weaning-to-first service interval and litter traits in a commercial landrace-large white swine population in northern Thailand. Asian-Aust. J. Anim. Sci. 23: 543-555.

Guedes RMC and Nogueira RHG (2001). The influence of parity order and body condition and serum hormones on weaning-to-estrus interval of sows. Anim. Reprod. Sci. 67: 91-99.

Hanenberg EHAT, Knol EF and Merks JWM (2001). Estimates of genetic parameters for reproduction traits at different parities in Dutch Landrace pigs. Liv. Prod. Sci. 69: 179-186.

Holm B, Bakken M, Vangen O and Rekaya R (2005). Genetic analysis of age at first service, return rate, litter size, and weaning-to-first service interval of gilts and sows. J. Anim. Sci. 83: 41-48.

Imboonta N, Rydhmer L and Tumwasorn S (2007). Genetic parameters for reproduction and production traits of Landrace sows in Thailand. J. Anim. Sci. 85: 53-59.

Karveliene B, Serniene L and Riskeviciene V (2008). Effect of different factors on weaning-to-first-service interval in Lithuanian pig herds. Vet. Ir Zootechinika 41: 64-69.

Kim HJ (2001). Genetic Parameters for Productive and Reproductive Traits of Sows in Multiplier Farms, PhD Thesis. Georg-August-University of Gottingen, Gottingen.

Koketsu Y and Dial GD (1997). Factors influencing the postweaning reproductive performance of sows on commercial farms. Theriogenology 47: 1445-1461.

Lundgren H, Canario L, Grandinson K, Lundeheim N, et al. (2010). Genetic analysis of reproductive performance in Landrace sows and its correlation to piglet growth. Liv. Sci. 128: 173-178.

Mabry JW, Culbertson MS and Reeves D (1996). Effects of lactation length on weaning-to-first-service interval, firstservice farrowing rate, and subsequent litter size. J. Swine Health Prod. 4: 186-188.

Meyer K (2003). SECATEURS: To "Prune" your Pedigree. Available at [http://agbu.une.edu.au/ kmeyer/prune.html]. Accessed October 15, 2008.

Misztal I (2002). REMLF90: Manual. 2002. Available at [http://nce.ads.uga.edu/ ignacy/numpub/blupf90/docs/remlf90. pdf]. Accessed October 21, 2008.

Noguera JL, Varona L, Babot D and Estany J (2002). Multivariate analysis of litter size for multiple parities with production traits in pigs: I. Bayesian variance component estimation. J. Anim. Sci. 80: 2540-2547.

Oh SH, Lee DH and See MT (2006). Estimation of genetics parameters for reproductive traits between first and later parities. Asian-Aust. J. Anim. Sci. 19: 7-12.

Poleze E, Bernardi ML, Filha WSA and Wents I (2006). Consequences of variation in weaning-to-estrus interval on reproductive performance of swine females. Liv. Sci. 103: 124-130.

Roehe R and Kennedy BW (1995). Estimation of genetic parameters for litter size in canadian yorkshire and landrace swine with each parity of farrowing treated as a different trait. J. Anim. Sci. 73: 2959-2970.

SAS (1999). User's Guide: Statistics Version 6. 4th edn. Statistical Analisys Sytem Institute, Cary.

Silveira PRS, Bortolozzo F, Wentz I and Sobestiansky J (1998). Manejo da Fêmea Reprodutora. In: Suinocultura Intensiva: Produção, Manejo e Saúde do Rebanho (Sobestiansky J, Wentz I and Silveira PRS, eds.). Embrapa-SPI, Brasília, 163-196.

Tantasuparuk W, Lundeheim N, Dalin AM, Kunavongkrit A, et al. (2000). Effects of lactation length and weaningto-service interval on subsequent farrowing rate and litter size in Landrace and Yorkshire sows in Thailand. Theriogenology 54: 1525-1536.

Ten Napel J and Johnson R (1997). Genetic relationships among production traits and rebreeding performance. J. Anim. Sci. 75: 51-60.

Ten Napel J, Kemp B, Luiting P and Vries AG (1995). A biological approach to examine genetic variation in weaning-tooestrus interval in first-litter sows. Liv. Prod. Sci. 41: 81-93. 
Tholen E, Bunter KL, Hermesch S and Graser HU (1996). The genetic foundation of fitness and reproduction traits in Australian pig populations. 2. Relationships between weaning to conception interval, farrowing interval, stayability, and other common reproduction and production traits. Aust. J. Agr. Res. 47: 1275-1290.

Tummaruk P, Lundeheim N, Einarsson S and Dalin AM (2000). Reproductive performance of purebred swedish landrace and swedish yorkshire sows: II. Effect of mating type, weaning-to-first-service interval and lactation length. Acta Agric. Scand., Seet. A, Anim. Sci. 50: 217-224. 